\title{
In Vitro Culture of Elite Sugarcane Cultivar (Saccharum spp) by Shoot Apical Meristem and Effect of Plant Hormones on Shoot Regeneration
}

\author{
R. Anitha ${ }^{1}$, M. Shanmuganathan ${ }^{2}$ and M. Jayachandran ${ }^{3}$ \\ ${ }^{1}$ Department of Crop Physiology, ${ }^{2}$ Department of Plant Breeding and Genetics, \\ ${ }^{3}$ Department of Agronomy, Sugarcane Research Station, Cuddalore \\ Tamil Nadu Agricultural University, Coimbatore, India \\ *Corresponding author
}

\begin{tabular}{|c|}
\hline Keywords \\
\hline $\begin{array}{l}\text { Auxin, Cytokinin, } \\
\text { in vitro, Apical } \\
\text { meristem, Shoot } \\
\text { regeneration }\end{array}$ \\
\hline Article Info \\
\hline $\begin{array}{l}\text { Accepted: } \\
12 \text { October } 2019 \\
\text { Available Online: } \\
10 \text { November } 2019\end{array}$ \\
\hline
\end{tabular}

\section{Introduction}

Sugarcane (Saccharum spp.) is a member of the Poaceae family and is an imperative cash crop. Sugarcane produces around $70 \%$ to $80 \%$ of sugar worldwide and $100 \%$ in India (Thorat et al., 2017). In India, sugarcane is cultivated under a wide range of agro-climatic conditions and secured a distinct position after cotton, and as an agro-industrial crop because of the prominent source of efficiently vital product (sugar) as well as by-products (bagasse, molasses and press mud) playing a major role in the economic progress of small and largescale industrial sectors.

In a tropical climate, the cultivation of sugarcane is more successful in terms of cane yield and sugar recovery throughout the year (Singh and Shami, 2017). 
Sugarcane is recognized as the most competent crop, which converts solar energy into harvestable chemical energy in the form of sucrose and biomass (Joyce et al., 2010). Sugarcane varieties are highly heterogeneous and usually multiplied by stem cutting method. The stems of sugarcane with two to three nodes are generally used for plantation in many tropical countries (Behara andSahoo, 2009). Owing to the unavailability of standardized multiplication procedure and contamination by systematic microorganism is the serious challenge to multiply an elite genotype of sugarcane (Thorat et al., 2016). However, plant tissue culture of sugarcane has received extensive research attention because of its economic consequence (Behara and Sahoo, 2009). During the past four decades, plant tissue culture is used for the large-scale micro propagation in commercial horticulture and agriculture worldwide (Das et al., 1996).

Generally, plant tissue culture technique is used for providing the highest number of healthy plantlets within the short duration, which is useful for rapid spreading of newly released sugarcane varieties in short duration (Fildmann et al., 1994). In sugarcane, explant like apical meristem (Devarumath et al., 2007), were used for rapid multiplication. During the process, to maintain genetic fidelity of the micro-propagated plantlets with respect to the mother plants are major concerns. Micro propagation is the only realistic means of achieving rapid, large-scale production of disease-free seed canes of newly developed varieties in order to speed up the breeding and commercialization process in Sugarcane (Lorenzo et al., 2001; Taylor and Dukie, 1993). Barba et al., (1978) reported that within 9 months of apical meristem produce planting material from a single spindle which was sufficient to plant a hectare of land. Lee (1987) also reported shoot tip culture for mass propagation of Sugarcane. This study was carried out to develop protocol for multiplication of elite sugarcane variety CoC25 grown in Tamil Nadu.

\section{Materials and Methods}

The variety CoC25 was selected based on their early maturity, high productivity and resistance to pests in different areas of Tamil Nadu. The explant plant materials were collected from the seed plot of Sugarcane Research Station, Cuddalore. All the experimental work was carried out at Sugarcane Research Station, Cuddalore during July 2018 to April 2019. The explant materials were taken from six months old sugarcane plants. Size of the apical meristem taken was 4 - $6 \mathrm{~mm}$. The explants were then cultured on MS (Murashige and Skoog`s medium 1962) supplemented with various combinations of BAP, $\mathrm{GA}_{3}$ and Kin for initiation of cultures, BAP, NAA, $\mathrm{GA}_{3}$ and tender coconut in liquid medium for the multiplication of cultures and with various levels of NAA for the rooting of cultures.

The media composition used for shoot initiation are $\mathrm{T}_{1^{-}}$MS+30g sucrose, $\mathrm{T}_{2^{-}}$ $\mathrm{MS}+0.1 \mathrm{mg} / \mathrm{l} \quad \mathrm{BAP}+0.015 \mathrm{mg} / \mathrm{l} \quad \mathrm{kin}+0.5 \mathrm{mg} / \mathrm{l}$ $\mathrm{GA}_{3}+30 \mathrm{~g}$ sucrose $+3.5 \mathrm{~g} / 1$ activated charcoal, $\mathrm{T}_{3}-\mathrm{MS}+0.2 \mathrm{mg} / \mathrm{l} \quad \mathrm{BAP}+0.1 \mathrm{mg} / \mathrm{l} \mathrm{kin}+0.5 \mathrm{mg} / \mathrm{l}$ $\mathrm{GA}_{3}+30 \mathrm{~g} \quad$ sucrose, $\mathrm{T}_{4^{-}} \quad \mathrm{MS}+0.3 \mathrm{mg} / \mathrm{l}$ $\mathrm{BAP}+0.5 \mathrm{mg} / 1 \quad \mathrm{GA}_{3}+30 \mathrm{~g}$ sucrose, $\mathrm{T}_{5^{-}}$ $\mathrm{MS}+0.5 \mathrm{mg} / \mathrm{l} \quad \mathrm{kin}+0.5 \mathrm{mg} / \mathrm{l} \quad \mathrm{GA}_{3}+30 \mathrm{~g}$ sucrose $+3.5 \mathrm{~g} / 1$ activated charcoal. The media composition used for shoot initiation and proliferation are $\mathrm{T}_{1^{-}} \mathrm{MS}+30 \mathrm{~g}$ sucrose, $\mathrm{T}_{2^{-}}$ $\mathrm{MS}+0.1 \mathrm{mg} / \mathrm{l} \quad \mathrm{BAP}+0.1 \mathrm{mg} / \mathrm{l} \quad \mathrm{kin}+0.5 \mathrm{mg} / \mathrm{l}$ $\mathrm{GA}_{3}+30 \mathrm{~g} \quad$ sucrose, $\quad \mathrm{T}_{3^{-}} \quad \mathrm{MS}+0.1 \mathrm{mg} / \mathrm{l}$ BAP $+0.1 \mathrm{mg} / \mathrm{l} \quad \mathrm{kin}+0.5 \mathrm{mg} / \mathrm{l} \quad \mathrm{GA}_{3}+0.1 \mathrm{mg} / \mathrm{l}$ $\mathrm{NAA}+30 \mathrm{~g} / \mathrm{l} \quad$ sucrose, $\quad \mathrm{T}_{4}-\mathrm{MS}+0.2 \mathrm{mg} / \mathrm{l}$ $\mathrm{BAP}+0.25 \mathrm{mg} / \mathrm{l} \quad \mathrm{kin}+0.5 \mathrm{mg} / \mathrm{l} \quad \mathrm{GA}_{3}+0.25 \mathrm{mg} / \mathrm{l}$ $\mathrm{NAA}+30 \mathrm{~g} / 1$ sucrose, $\mathrm{T}_{5^{-}} \quad \mathrm{MS}+0.25 \mathrm{mg} / \mathrm{l}$ $\mathrm{BAP}+0.5 \mathrm{mg} / \mathrm{l} \quad \mathrm{kin}+1.0 \mathrm{mg} / \mathrm{l} \quad \mathrm{GA}_{3}+0.5 \mathrm{mg} / \mathrm{l}$ NAA $+30 \mathrm{~g} / \mathrm{l}$ sucrose. The media composition used for root initiation are $\mathrm{T}_{1^{-}} 1 / 2 \mathrm{MS}+0.5 \mathrm{mg} / \mathrm{l}$

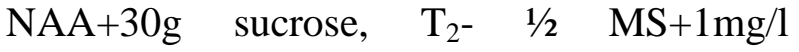


NAA+40g/l sucrose, $\quad \mathrm{T}_{3^{-}} \quad 1 / 2 \quad \mathrm{MS}+2 \mathrm{mg} / \mathrm{l}$ NAA+40g/l sucrose, $\mathrm{T}_{4^{-}} \quad 1 / 2 \quad \mathrm{MS}+3 \mathrm{mg} / \mathrm{l}$ NAA+40g/l sucrose, $\mathrm{T}_{5^{-}} \quad 1 / 2 \quad \mathrm{MS}+4 \mathrm{mg} / \mathrm{l}$ NAA+40g/l sucrose, $\mathrm{T}_{6^{-}} \quad 1 / 2 \quad \mathrm{MS}+4 \mathrm{mg} / \mathrm{l}$ NAA+40g/l sucrose. Data in case of shoot initiation were recorded 20 days after culturing, for shoot multiplication 30 days after culturing and for rooting 20 days after culturing. The documented data on various observations were analyzed statistically.

\section{Results and Discussion}

Shoot tips with apical meristem were found excellent starting material for the micro propagation of sugarcane. Anita et al., (2000) also used shoot tip as explant source for mass micro propagation of sugarcane crop, which supported strongly our choice of explant selection. Rapid shoot growth occurred when shoot tips were used as explants for micro propagation inoculated on MS medium.

Interaction of shoot initiation with hormones BAP, Kin and $\mathrm{GA}_{3}$

The protocol identified through the present study was an easy and efficient one for sugarcane mass micro propagation which can be easily repeated for the improvement of sugarcane crop. The different hormonal combinations attributed highly significant $(\mathrm{P}<$ 0.01) impact on growth percentages of shoot tips (Figure 1). Growth percentages for different hormones ranged from 18.33 to $85.50 \%$, where MS+30g sucrose $\left(\mathrm{T}_{1}\right)$ showed the lowest value of $18.33 \%$ and $\mathrm{MS}+0.1 \mathrm{mg} / \mathrm{l}$ $\mathrm{BAP}+0.015 \mathrm{mg} / \mathrm{l} \quad \mathrm{kin}+0.5 \mathrm{mg} / \mathrm{l} \quad \mathrm{GA}_{3} \quad+30 \mathrm{~g}$ sucrose $+3.5 \mathrm{~g} / \mathrm{l}$ activated charcoal $\left(\mathrm{T}_{2}\right)$ showed the highest value of $85.50 \%$ (Table 1). Our results are in line with those of Anita et al., (2000), because they also reported shoot tip as explant source for in vitro mass micro propagation of sugarcane crop. The reason might be that shoot tip is much safer and fast growing portion of the plant.
The hormones combinations recorded highly significant $(\mathrm{P}<0.01)$ interaction. The different hormones combinations showed highly significant $(\mathrm{P}<0.01)$ impact on average shoots length of shoot tips. The average shoot length ranged from $2.5 \mathrm{~cm}$ for $\mathrm{MS}+30 \mathrm{~g}$ sucrose $\quad\left(\mathrm{T}_{1}\right)$ to $\quad 9.2 \mathrm{~cm}$ forMS $+0.1 \mathrm{mg} / \mathrm{l}$ $\mathrm{BAP}+0.015 \mathrm{mg} / \mathrm{l} \quad \mathrm{kin}+0.5 \mathrm{mg} / \mathrm{l} \quad \mathrm{GA}_{3} \quad+30 \mathrm{~g}$ sucrose $+3.5 \mathrm{~g} / \mathrm{l}$ activated charcoal $\left(\mathrm{T}_{2}\right)$ (Table 1).

Razi-ud-Din et al., (2004) reported maximum shoot growth of $83.3 \%$ with average shoot length of $3.7 \mathrm{~cm}$ when using MS medium supplemented with $5.0 \mathrm{mg} / \mathrm{l} \mathrm{BAP}$ and $1.0 \mathrm{mg} / \mathrm{l}$ GA3, but the present study we observed that maximum growth of $85 \%$ for the variety $\mathrm{CoC} 25$ at $0.1 \mathrm{mg} / \mathrm{lBAP}, 0.015 \mathrm{mg} / \mathrm{l}$ kinetin and $0.5 \mathrm{mg} / \mathrm{l} \mathrm{GA}_{3}$.Similarly different hormones combinations showed highly significant $(\mathrm{P}<$ $0.01)$ impact on leaves number. The average leaves number ranged from 2 to 7 where MS+30g sucrose $\left(\mathrm{T}_{1}\right)$ showed the lowest value of 2 and $\mathrm{MS}+0.1 \mathrm{mg} / \mathrm{l} \quad \mathrm{BAP}+0.015 \mathrm{mg} / \mathrm{l}$ kin $+0.5 \mathrm{mg} / 1 \quad \mathrm{GA}_{3}+30 \mathrm{~g} \quad$ sucrose $+3.5 \mathrm{~g} / \mathrm{l}$ activated charcoal $\left(\mathrm{T}_{2}\right)$ showed the highest value of 7 (Table 1).

\section{Shoot multiplication of variety $\mathrm{CoC25}$}

Multiplication of cultures, initiated on solid medium was carried out on liquid medium with four different combinations of BAP, Kin, NAA and $\mathrm{GA}_{3}$ along with control.

\section{Effects of different concentrations and combinations of BAP, Kin, NAA and $\mathrm{GA}_{3}$ on multiplication of sugarcane variety}

Chattha et al., (2001) and Jadhav et al., (2001) reported that different genotypes give shoots on different media. Wongkaew and Fletcher (2004) used MS medium containing $0.5 \mathrm{mg} / \mathrm{l}$ NAA, $0.5 \mathrm{mg} / \mathrm{l} \mathrm{BAP}$ and $15 \%$ coconut water for the growth initiation of meristem tips. The different hormones combinations showed 
highly significant $(\mathrm{P}<0.01)$ impact on average shoot length (Figure 1). The shoot length ranged from $1.5 \mathrm{~cm}$ forMS+30g sucrose $\left(\mathrm{T}_{1}\right)$ to $13.25 \mathrm{~cm}$ for $\mathrm{MS}+0.25 \mathrm{mg} / \mathrm{l}$ $\mathrm{BAP}+0.5 \mathrm{mg} / \mathrm{l} \quad \mathrm{kin}+1.0 \mathrm{mg} / \mathrm{l} \quad \mathrm{GA}_{3}+0.5 \mathrm{mg} / \mathrm{l}$ NAA $+30 \mathrm{~g} / \mathrm{l}$ sucrose $\left(\mathrm{T}_{5}\right)$ (Table 2$)$. Khan and Rashid (2003) reported shoot tip initiation on Kin and $\mathrm{GA}_{3}$ with 5 leaves per plant which is very much similar to our results.

The different hormones combinations also showed highly significant $(\mathrm{P}<0.01)$ impact on number of tillers. The number of tillers ranged from 0 for $\mathrm{MS}+30 \mathrm{~g}$ sucrose $\left(\mathrm{T}_{1}\right)$ to 7.5 for $\mathrm{MS}+0.25 \mathrm{mg} / \mathrm{l} \mathrm{BAP}+0.5 \mathrm{mg} / \mathrm{l} \mathrm{kin}+1.0 \mathrm{mg} / \mathrm{l}$ $\mathrm{GA}_{3}+0.5 \mathrm{mg} / 1 \mathrm{NAA}+30 \mathrm{~g} / \mathrm{l}$ sucrose $\left(\mathrm{T}_{5}\right)($ Table 2). Cheema and Hussain (2004) observed 29 shoots per plant at $0.4 \mathrm{mg} / \mathrm{l} \mathrm{BAP}$ in combination with $0.4 \mathrm{mg} / \mathrm{l} \mathrm{Kin}$.

The different hormones combinations showed significant $(\mathrm{P}<0.05)$ impact on Chlorophyll content of $1.134 \mathrm{mg} / \mathrm{g}$ for $\mathrm{MS}+30 \mathrm{~g}$ sucrose $\left(\mathrm{T}_{1}\right)$ to $8.652 \mathrm{mg} / \mathrm{g}$ for $\mathrm{MS}+0.25 \mathrm{mg} / \mathrm{l}$ $\mathrm{BAP}+0.5 \mathrm{mg} / \mathrm{l} \quad \mathrm{kin}+1.0 \mathrm{mg} / \mathrm{l} \quad \mathrm{GA}_{3}+0.5 \mathrm{mg} / \mathrm{l}$ NAA $+30 \mathrm{~g} / 1$ sucrose $\left(\mathrm{T}_{5}\right)$ (Table 2$)$.

The leaves were dark green in color initially but changed to light green and in some cases yellowish after some time. It was observed that chlorophyll content is highest in the in vitro plants $(8.652 \mathrm{mg} / \mathrm{g})$ as they were growing under optimal nutritional as well as temperature and illumination condition provided in the growth chamber. The experimental plants experience a climate change during acclimatization which affects the overall growth of the plant but it regains its normal growth after acclimatization when transferred to the field conditions.

\section{Rooting of sugarcane plantlets}

The shoots of 8 to $10 \mathrm{~cm}$ in size with multiple leaves were transferred to rooting medium. Growth hormone NAA with six different concentrations were used (Figure 1). From the study it was found that root initiation started in this variety of sugarcane after 6 to 10 days.

Rooting response of this variety were observed on half strength liquid Murashige and Skoog medium supplemented with various concentrations of NAA with $40 \mathrm{~g} / \mathrm{l}$ sucrose. There were differences in the response of different concentrations however NAA 0.5 - $5.0 \mathrm{mg} / \mathrm{l}$ responded well.

\section{Effects of different concentrations of NAA on rooting of variety $\mathrm{CoC} 25$}

The average root number for the variety CoC25 were recorded highly significant $(\mathrm{P}<$ $0.01)$ different. The average number of roots ranged from 6 to 35. The highest value (35) was observed at $5.0 \mathrm{mg} / \mathrm{l}$ NAA while the lowest value (6) was observed for $0.5 \mathrm{mg} / \mathrm{l}$ NAA (Table 3). The control for low concentration of NAA hormone failed to produce any root inCoC25. Root length for variety $\mathrm{CoC} 25$ was highly significant $(\mathrm{P}<$ $0.01)$ ) for different treatments. The mean root length ranged from $1.0 \mathrm{~cm}$ at $0.5 \mathrm{mg} / 1 \mathrm{NAA}$ and $3.05 \mathrm{~cm}$ at $5.0 \mathrm{mg} / \mathrm{l}$ NAA. Baksha et al., (2002) used $5.0 \mathrm{mg} / \mathrm{l}$ NAA for best response of rooting in half strength MS medium. This suggests use of high concentration of NAA for rooting purpose as the best root initiation growth hormone with highest number of 41 roots per plant. Mamun et al., (2004) obtained best results of rooting on MS medium supplemented with auxins (NAA +IBA) 0.5 $\mathrm{mg} / \mathrm{l}$ for each one. From the present study it was found that NAA $5.0 \mathrm{mg} / 1$ was best for optimum root growth for the variety $\mathrm{CoC} 25$ but at the low concentration of NAA produced only 6 roots per plant. Ali and Afghan (2001) observed only 6 - 7 roots after 3 weeks on MS medium containing $2 \mathrm{mg} / \mathrm{l}$ IBA and $6 \%$ sucrose but the present study reported 35 roots per plant which are much higher number as compared to their results. 
Table.1 List of media composition used for shoot initiation in sugarcane varCoC25

\begin{tabular}{|c|c|c|c|c|}
\hline S.No & Treatments & $\begin{array}{c}\text { Growth } \\
\text { percentage }\end{array}$ & $\begin{array}{c}\text { Shoot } \\
\text { length } \mathrm{cm}\end{array}$ & $\begin{array}{l}\text { No. of } \\
\text { leaves }\end{array}$ \\
\hline $\mathbf{T}_{1}$ & $\mathrm{MS}+30 \mathrm{~g}$ sucrose & 18.33 & 2.5 & 2 \\
\hline $\mathbf{T}_{2}$ & $\begin{array}{l}\mathrm{MS}+0.1 \mathrm{mg} / \mathrm{l} \mathrm{BAP}+0.015 \mathrm{mg} / \mathrm{lkin}+0.5 \mathrm{mg} / 1 \mathrm{GA} \mathrm{A}_{3} \\
\quad+30 \mathrm{~g} \text { sucrose}+3.5 \mathrm{~g} / \mathrm{l} \text { activated charcoal }\end{array}$ & 85.50 & 9.2 & 7 \\
\hline $\mathbf{T}_{3}$ & $\begin{array}{c}\mathrm{MS}+0.2 \mathrm{mg} / \mathrm{l} \mathrm{BAP}+0.1 \mathrm{mg} / \mathrm{lkin}+0.5 \mathrm{mg} / \mathrm{lGA}_{3} \\
+30 \mathrm{~g} \text { sucrose }\end{array}$ & 60.20 & 6.3 & 5 \\
\hline $\mathbf{T}_{4}$ & $\mathrm{MS}+0.3 \mathrm{mg} / \mathrm{BAP}+0.5 \mathrm{mg} / \mathrm{GGA}_{3}+30 \mathrm{~g}$ sucrose & 78.23 & 7.5 & 6.6 \\
\hline $\mathbf{T}_{5}$ & $\begin{array}{c}\mathrm{MS}+0.5 \mathrm{mg} / \mathrm{lkin}+0.5 \mathrm{mg} / 1 \mathrm{GA}_{3}+30 \mathrm{~g} \\
\text { sucrose }+3.5 \mathrm{~g} / \mathrm{l} \text { activated charcoal }\end{array}$ & 56.50 & 5.5 & 4 \\
\hline & SEm+ & 3.8 & 0.48 & 0.56 \\
\hline & $\mathrm{CD}$ & 12.47 & 1.56 & 1.83 \\
\hline
\end{tabular}

Table.2 List of media composition used for shoot initiation and proliferation in sugarcane varCoC25

\begin{tabular}{|c|c|c|c|c|}
\hline S.No & Treatments & $\begin{array}{c}\text { Shoot } \\
\text { length } \\
\text { cm }\end{array}$ & $\begin{array}{c}\text { Number of } \\
\text { tillers }\end{array}$ & $\begin{array}{c}\text { Chlorophyll } \\
\text { content } \\
\text { mg/g }\end{array}$ \\
\hline$T_{1}$ & MS $+30 \mathrm{~g}$ sucrose & 1.5 & 0.0 & 1.134 \\
\hline $\mathbf{T}_{2}$ & $\begin{array}{l}\mathrm{MS}+0.1 \mathrm{mg} / \mathrm{lBAP}+0.1 \mathrm{mg} / / \mathrm{kin}+0.5 \mathrm{mg} / 1 \mathrm{GA}_{3}+30 \\
\text { g sucrose }\end{array}$ & 8.5 & 5 & 3.421 \\
\hline $\mathbf{T}_{3}$ & $\begin{array}{l}\mathrm{MS}+0.1 \mathrm{mg} / \mathrm{lBAP}+0.1 \mathrm{mg} / \mathrm{lkin}+0.5 \mathrm{mg} / \mathrm{lGA}_{3}+0 . \\
1 \mathrm{mg} / \mathrm{l} \mathrm{NAA}+30 \mathrm{~g} / \mathrm{l} \text { sucrose }\end{array}$ & 9.1 & 3.5 & 4.760 \\
\hline $\mathbf{T}_{4}$ & $\begin{array}{l}\mathrm{MS}+0.2 \mathrm{mg} / \mathrm{lBAP}+0.25 \mathrm{mg} / / \mathrm{kin}+0.5 \mathrm{mg} / \mathrm{lGA}_{3}+0 \\
.25 \mathrm{mg} / \mathrm{l} \mathrm{NAA}+30 \mathrm{~g} / \mathrm{lsucrose}\end{array}$ & 11.52 & 5.5 & 6.785 \\
\hline $\mathbf{T}_{5}$ & $\begin{array}{l}\mathrm{MS}+0.25 \mathrm{mg} / \mathrm{lBAP}+0.5 \mathrm{mg} / \mathrm{lkin}+1.0 \mathrm{mg} / \mathrm{lGA}_{3}+0 \\
.5 \mathrm{mg} / \mathrm{l} \mathrm{NAA}+30 \mathrm{~g} / \mathrm{l} \text { sucrose }\end{array}$ & 13.25 & 7.5 & 8.652 \\
\hline & SEm+ & 0.49 & 0.26 & 0.22 \\
\hline & CD & 1.59 & 0.85 & 0.72 \\
\hline
\end{tabular}

Table.3 List of media composition used for root initiation in sugarcane varCoC25

\begin{tabular}{|c|c|c|c|}
\hline S.No & Treatments & No. of roots & $\begin{array}{l}\text { Root length } \\
\text { (cm) }\end{array}$ \\
\hline $\mathbf{T}_{1}$ & $1 / 2 \mathrm{MS}+0.5 \mathrm{mg} / \mathrm{lNAA}+30 \mathrm{~g}$ sucrose & 6 & 1.00 \\
\hline $\mathbf{T}_{2}$ & $1 / 2 \mathrm{MS}+1 \mathrm{mg} / 1 \mathrm{NAA}+40 \mathrm{~g} / 1$ sucrose & 15 & 1.40 \\
\hline $\mathbf{T}_{3}$ & $1 / 2 \mathrm{MS}+2 \mathrm{mg} / \mathrm{l} \mathrm{NAA}+40 \mathrm{~g} / \mathrm{l}$ sucrose & 19 & 2.15 \\
\hline $\mathbf{T}_{4}$ & $1 / 2 \mathrm{MS}+3 \mathrm{mg} / \mathrm{l} \mathrm{NAA}+40 \mathrm{~g} / \mathrm{l}$ sucrose & 23 & 1.75 \\
\hline $\mathbf{T}_{5}$ & $1 / 2 \mathrm{MS}+4 \mathrm{mg} / 1 \mathrm{NAA}+40 \mathrm{~g} / 1$ sucrose & 29 & 2.95 \\
\hline \multirow[t]{3}{*}{$\mathbf{T}_{6}$} & $1 / 2 \mathrm{MS}+4 \mathrm{mg} / 1 \mathrm{NAA}+40 \mathrm{~g} / 1$ sucrose & 35 & 3.05 \\
\hline & SEm+ & 1.01 & 0.38 \\
\hline & $\mathrm{CD}$ & 3.20 & 1.20 \\
\hline
\end{tabular}


Apical meristem inoculated test tube, C,D- Grownup Apical meristem, E- Shoot multiplication

F- Shoots in multiplication medium, G- Grownup plants
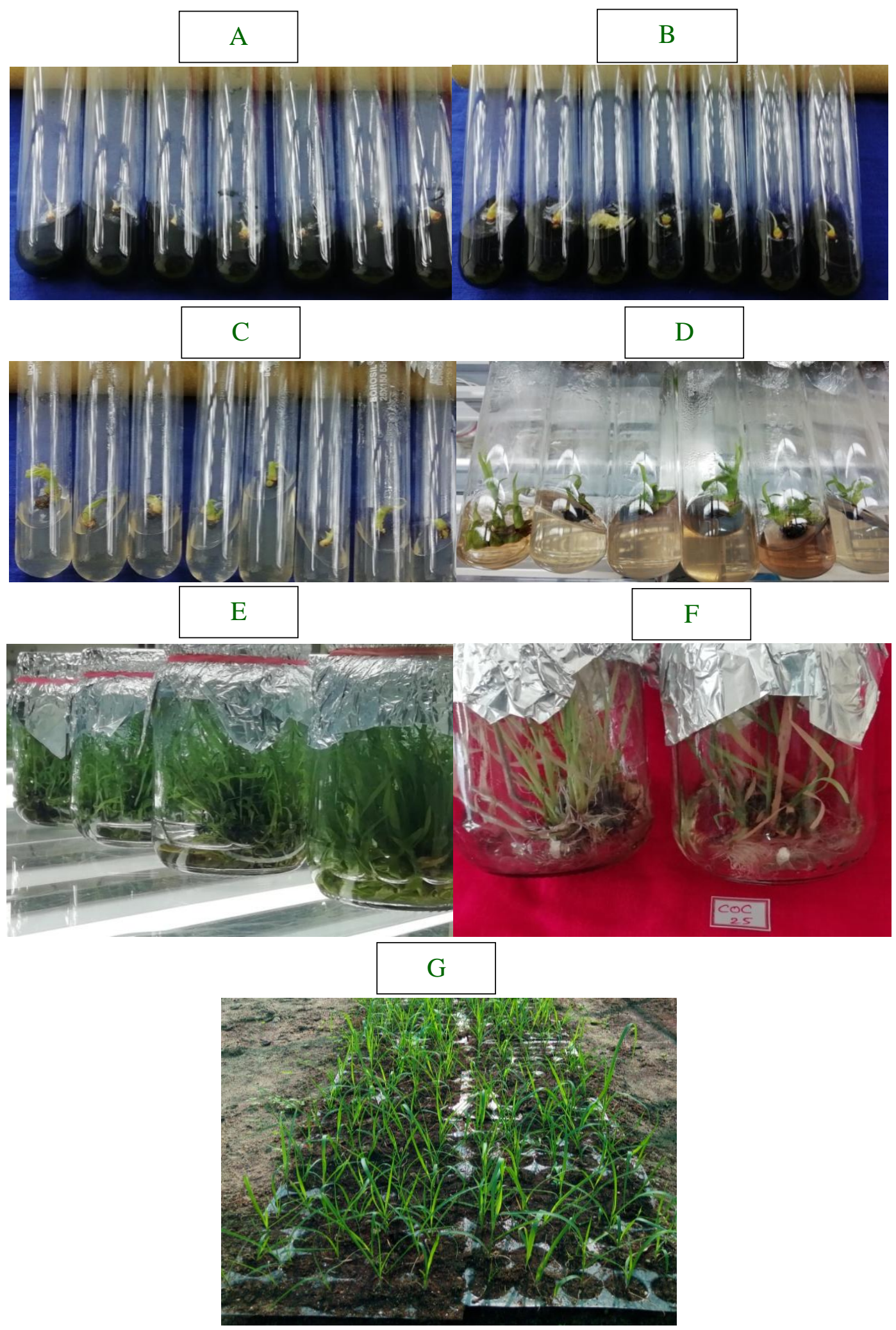


\section{Acclimatization}

The rooted plantlets were transferred to portray and covered with polythene bags for high humidity for 2 - 3 days. After that these were transferred to soil in growth room for few days and then these were transferred to green house to assess their potential for further hardening. The acclimatization potential was $70-80 \%$.Micropropagation of sugarcane from shoot tip may become the successful method to cope with the present day demand. It will be an easy way for obtaining intensive number of plants in limited time under controlled conditions. Through the use of tissue culture technique it may be easy to obtain disease free plants. The protocol used in the present study can be used for rapid multiplication of sugarcane especially for the variety CoC 25 .

\section{References}

Ali K, Afghan S (2001). Rapid multiplication of sugarcane through micro propagation technique. Pak. Sugar J. 16(6): 11-14.

Anita P, Jain RK, Schrawat AR, Punia A (2000). Efficient and cost effective micropropagation of two early maturing varieties of sugarcane (Saccharum spp.). Indian Sugar, 50: 611-618.

Baksha R, Alam R, Karim M.Z, Paul, SK, Hossain MA, Miah MAS, Rahman ABMM (2002). In vitro shoot tip culture of sugarcane (Saccharum officinarum) variety LSD28. Biotechnology, 1(2-4): 67-72.

Barba RC, Zamora AB, Malion AK, Linga CK (1978). Sugarcane tissue culture research. Proc. Int. Soc. Sugarcane Technol. 16: 1843-1863.

Behara KK, Sahoo S (2009) Rapid in-vitro micro propagation of sugarcane (Saccharum officinarumL. cv-Nayana) through callus culture. Nature and Science 7(4): 1-10

Chattha MA, Abida A, Muhammad I, Akhtar A (2001). Micro propagation of sugarcane (Saccharum species hybrid). Pak. Sugar J. 16: 2-6.

Cheema KL, Hussain M (2004). Micro propagation of sugarcane through apical bud and axillary bud. Int. J. Agric. Biol. 2: 257-259.

Das S, Jha TB, Jha S (1996) Stratergies for improving of Cashewnut through Tissue culture. In: Plant Tissue Culture. Islam AS (ed.) Oxford and IBH Publishing Co. Pvt. Ltd. Ltd. 1-7

Devarumath RM, Doule RB, Kawar PG, Naikebawane SB, Nerkar YS (2007) Field performance and RAPD analysis to evaluate genetic fidelity of tissue culture raised plants vis-a-vis conventional setts derived plants of sugarcane. Sugar Tech 9:17-22

Fildmann P, Sapotille J, Gredoire P, Rott P (1994). Micropropagation of sugarcane. In: Teisson $\mathrm{C}$, ed. In vitro culture of tropical plants. France 1517.

Jadhav AB, Vaidya ER, Aher VB, Pawar AM (2001). In vitro multiplication of $\mathrm{Co}-$ 86032 sugarcane (S. officinarum) hybrid. Indian J. Agric. Sci. 71: 113115.

Joyce P, Kuwahata M, Turner and N, Lakshmanan P (2010) Selection system and co-cultivation medium are important determinants of Agrobacterium-mediated transformation of sugarcane. Plant Cell Reports 29:173-183.

Khan MR, Rashid H (2003). Studies on the rapid clonal propagation of Saccharum officinarum. Pak. J. Biol. Sci. 6(22): 1876-1879.

Lee TSG (1987). Micropropagation of sugarcane (Saccharum spp.) Plant Cell Tissue Org. Cult. 10: 47-55. 
Lorenzo JC, Ojeda E, Espinosa A, Borroto C (2001). Field performance of temporary immersion bioreactor derived sugarcane plants. In vitro cell Dev. Biol., Plant, 37: 803-806.

Mamun MA, Skidar MBH, Paul DK, Rehman MM, Islam M (2004). In vitro micro propagation of some important sugarcane varieties of Bangladesh. Asian J. Plant Sci. 3(6): 666-669.

Mstat-C (1991). Michigan State University, East Lansing, USA

Murashige T, Skoog F (1962). A revised medium for rapid growth and bioassays with tobacco tissue culture. Plant Physiol., 9: 473-497.

Razi-ud-Din, Salim Shah S, WaqusHussan S, Ali S, Zamir R (2004). Micropropagation of sugarcane though bud culture. Sarhad J. Agri. 20: 1.

Singh NP and Shami V (2017) Abiotic stress tolerance in sugarcane using genomics and proteomics techniques. In: KalpanaSengar (ed) Biotechnology to Enhance Sugarcane Productivity and Stress Tolerance. CRC Press, Boca Raton, FL.
Taylor PWJ, Dukie S (1993). Development of an in vitro culture technique for conservation of Saccharum Sp. Plant cell Tissue Organ Cult. 34: 217-222.

Thorat AS, Muley AB, Shingote PR, Nalavade VM, K. H. Babu (2016) Establishment of sterilization method for reducing microbial contamination for emergent quality of sugarcane (Saccharum officinarum L.) in an efficient micropropagation system. Res. J. Pharm. Biol. Chem. Sci. 7(2): 11221135.

Thorat AS, Sonone NA, Choudhari VV, Devarumath RM and K.H. Babu (2017) Plant regeneration from cell suspension culture in Saccharum officinarumL. and ascertaining of genetic fidelity through RAPD and ISSR markers. 3 Biotech (2017) 7: 16.10.1007/s13205-016-0579-3

Wongkaew P, Fletcher J (2004). Sugarcane white leaf phytoplasma in tissue culture, long term maintenance, transmission and Oxy tetracycline remission. Plant Cell Rep., 23: 426434.

\section{How to cite this article:}

Anitha, R., M. Shanmuganathan and Jayachandran, M. 2019. In Vitro Culture of Elite Sugarcane Cultivar (Saccharum spp) by Shoot Apical Meristem and Effect of Plant Hormones on Shoot Regeneration. Int.J.Curr.Microbiol.App.Sci. 8(11): 1279-1286.

doi: https://doi.org/10.20546/ijcmas.2019.811.151 